\title{
Molecular characterization of Mannheimia haemolytica isolates associated with pneumonic cases of sheep in selected areas of Central Ethiopia
}

Abinet Legesse ${ }^{1}$, Takele Abayneh ${ }^{1 *} \mathbb{D}$, Gezahegne Mamo ${ }^{2}$, Esayas Gelaye ${ }^{1}$, Liyuwork Tesfaw ${ }^{1}$, Martha Yami ${ }^{1}$ and Alebachew Belay ${ }^{1}$

\begin{abstract}
Background: Mannheimia haemolytica has been recognized as the principal cause of pneumonic pasteurellosis in sheep and goats. It is one of the important diseases of small ruminants in Ethiopia. While annual vaccination using a monovalent vaccine (inactivated Pasteurella multocida biotype A) is common, respiratory diseases are still reported in various parts of Ethiopia. This suggests the need for further investigation into the species and strains responsible for the disease, which is vital information for development of a multivalent vaccine. The objective of the current study was to isolate M. heamolytica associated with pneumonic cases of sheep in selected areas of Central Ethiopia, determine its role and the strains/genotypes of the bacterium circulating in the study area.

Results: Bacteriological analysis of nasal swab samples collected from a total of 76 pneumonic cases of sheep showed that M. haemolytica was isolated from 26 of them while B.trehalosi from two cases. Further molecular analyses of the isolates using M. haemolytica species-specific and M.haemolytica serotype-1 antigen specific PCR assays revealed, 26 of the isolates were identified as M. haemolytica of which 21 of them were M. haemolytica serotype-1. Both M. haemolytica and B.trehalosi isolates were not detected in a PCR assay targeting capsular biosynthesis gene (capA) of P.multocida despite the non-specific products observed in M. haemolytica isolates. Phylogenetic analysis of $M$. haemolytica isolates included in this study in comparison with the reference strains with respect to PHSSA and Rpt2 genes revealed that the Ethiopian M. haemolytica isolates constituted three distinct genotypes consistent with site of origin.

Conclusion: The study indicated that M.haemolytica is commonly associated with cases of pneumonia in sheep in the study areas of central Ethiopia although the remaining other pathogens responsible for majority of the cases are yet to be determined. Molecular characterization revealed the existence of three genotypes of $M$. haemolytica circulating in the study areas consistent to the site of isolation. The findings suggest further extensive work to determine all pathogens associated with sheep pneumonia and the strain distribution of M. heamolytica to understand its molecular epidemiology at national level and design cost effective prevention and control methods.
\end{abstract}

Keywords: Central Ethiopia, Mannheimia haemolytica, Molecular characterization, Sheep

\footnotetext{
* Correspondence: takeletefera99@gmail.com

${ }^{1}$ National Veterinary Institute, P.O. Box 19, Bishoftu, Ethiopia

Full list of author information is available at the end of the article
}

(c) The Author(s). 2018 Open Access This article is distributed under the terms of the Creative Commons Attribution 4.0 International License (http://creativecommons.org/licenses/by/4.0/), which permits unrestricted use, distribution, and reproduction in any medium, provided you give appropriate credit to the original author(s) and the source, provide a link to the Creative Commons license, and indicate if changes were made. The Creative Commons Public Domain Dedication waiver (http://creativecommons.org/publicdomain/zero/1.0/) applies to the data made available in this article, unless otherwise stated. 


\section{Introduction}

Sheep constitute a significant proportion of the Ethiopian livestock industry, with the total population estimated at 26.1 million $[1,2]$. However, the productivity of sheep is unsatisfactory largely due to diseases and poor animal management practices $[3,4]$.

Diseases causing respiratory problems in sheep have been known of great economic impact in the central highlands of Ethiopia with frequent records of outbreaks and mortalities [5].

Ovine pasteurellosis is one of the important respiratory diseases of sheep responsible for the low productivity due to economic losses resulting from death, reduced live weight, delayed marketing, treatment cost and un-thriftiness among survivors [6-8]. The term pasteurellosis was broadly used to designate a number of infections in domestic animals mainly caused by three species notably $M$. haemolytica, B. trehalosi and P. multocida. These bacterial species are non-motile, non-sporing, aerobic, fermentative, Gram negative rod and cocco-bacilli usually being pleomorphic $[9,10]$. They can normally exist as commensals in the respiratory tract of cattle, sheep, and other ruminants [11-13].

The disease in sheep is characterized by an acute infection with high fever $\left(40.4{ }^{\circ} \mathrm{C}\right.$ to $\left.42^{\circ} \mathrm{C}\right)$, coughing, dyspnea, muco-purulent nasal discharge, anorexia and depression [14] that commonly develops when the immune system of the animal is compromised by stress factors such as crowding, transportation, draught, and inclement weather [15].

Pneumonic pasteurellosis is primarily caused by $M$. haemolytica [16] and is one of the major causes of mortality in domestic ruminants [17]. Apart from lung infection, M. haemolytica is also associated with systemic infections in small ruminants [17]. The taxon name Mannheimia haemolytica came into being after a number of works on reclassification and naming, first as Bacterium bipolare multocidum designated by Theodore kitt in1885 [18] and later in 1932 as Pasteurella haemolytica [18]. P. haemolytica was then classified into two biotypes viz. $\mathrm{A}$ and $\mathrm{T}$ based on its ability to ferment the sugars arabinose and trehalose, respectively [18]. These biotypes were further subdivided into thirteen A serotypes (A1, A2, A5, A6, A7, A8, A9, A11, A12, A13, A14, A16 and A17) and four $T$ serotypes (serotypes $3,4,10$ and 15) based on capsular antigen typing using Indirect Haemagglutination Test [19]. Pasteurella haemolytica biotype A was later allocated to a new genus Mannheimia and renamed as Mannheimia haemolytica while the $4 \mathrm{~T}$ serotypes were named Bibersteinia trehalosi. Recently, however, serotype A11 is classified into a new taxon as $M$. glucosida due to its different biochemical profile, leaving twelve serotypes of $M$. heamolytica [20].

Few studies have been conducted in northern, central highlands and eastern Ethiopia to determine the extent of the problem and the relative distribution of the different biotypes and serotypes of $M$. haemolytica. The studies indicated that ovine pasteurellosis is a major threat to sheep production and most serotypes of $M$. haemolytica biotype A are involved in causing pneumonic pasteurellosis with serotype A2 being the most prevalent [5, 20-23].

Since pneumonic pasteurellosis is one of the serious problems of small ruminants, effective control and prevention of the disease is mandatory. The traditional therapy based on the extensive use of antibiotics, including mass medication of animals, has caused an increase in the incidence of multi-drug resistant $M$. haemolytica strains in many parts of the world [24, 25]. Hence, an alternative prophylactic strategy through vaccination is more desirable.

In Ethiopia, a monovalent vaccine (inactivated P. multocida biotype A) produced at the National Veterinary Institute (Ethiopia) is being used for vaccination against ovine pasteurellosis although studies in central highlands of Ethiopia indicate $M$. haemolytica serotype A2 and A7 were reported to occur at high frequency $[5,26]$. Although there is no published report on the efficacy of the currently used vaccine under field conditions, customer complaints on the high rates of mortality and morbidity following respiratory distress in different parts of the country have been documented despite the annual vaccination. This may suggest the need for the development of a multivalent vaccine using the most prevalent serotypes [5]. However, there is a need of an extensive study on identification of the prevalent serotypes in the country to be considered for inclusion into multivalent vaccine.

Despite the few reports on the serotypes of $M$. haemolytica circulating in Ethiopia, information on the genotypes of $M$. haemolytica associated with pneumonic cases in sheep in central Ethiopia is lacking which is essential for designing appropriate vaccine and molecular detection assays. Therefore, this study is aimed at identification and molecular characterization of $M$. haemolytica isolated from pneumonic cases of sheep in selected areas in central Ethiopia.

\section{Methods}

\section{Study areas and animals}

The study was conducted from November 2016 to May 2017 in four selected areas of central Ethiopia, which include Addis Ababa and three districts viz. Ada'a, Lome and Adama. All the study sites are located within the range of $100 \mathrm{~km}$ South East of Addis Ababa. Cases of sheep suffering from respiratory distress were purposively included in the present study for bacteriological analysis. Accordingly, pneumonic individual cases presented to veterinary clinics/veterinary health posts of the study districts/sites were considered for sampling. Since all cases were sampled from different farmers, it is assumed that each case originated from a different flock or herds. 


\section{Sampling}

All sheep were clinically examined and those with signs of anorexia, coughing, dyspnea, lethargy, serous to muco-purulent nasal discharge, and fever were considered for sampling. Accordingly, a total of 76 cases suspected of pneumonic pastuerellosis were included in the study comprising 11 from Addis Ababa, 27 from Ada'a, 17 from Lome and 21 from Adama.

After disinfection of external part of the nose with $70 \%$ alcohol, nasal swabs were collected from the nostrils using sterile cotton swabs as described previously by Carter [27-29]. The swabs were placed in labeled sterile test tubes that contain $2 \mathrm{~mL}$ of Amies transport medium (OXOID Hampshire, England) and was then kept in an ice box during transportation to the National Veterinary Institute.

\section{Bacteriological analysis}

Isolation and identification of M.haemolytica, B.trehalosi and P.multocida was performed at bacteriology laboratory of the National Veterinary Institute as per the standard bacteriological techniques described previously [27, 28].

Nasal swabs were directly streaked onto blood agar base (Parck scientific limited, Northampton, UK) supplemented with $5 \%$ defibrinated sheep blood followed by incubation at $37^{\circ} \mathrm{C}$ for $24-48 \mathrm{~h}$.

In culture positive plates, typical suspected colonies (at least three colonies from a single plate) were picked and gram stained. Those colonies with gram reaction and colony morphology consistent to Pasteurella species were further sub-cultivated on blood and MacConkey agar plates (Himedia, India) to get pure cultures for further analysis. Pure cultures of single colony type from MacConkey agar was transferred onto nutrient agar (TSA) for a series of primary tests including tests for motility using mannitol motility medium, catalase (Fisher Chemical, UK), oxidase (Merck Co., Germany) and fermentative/oxidative tests using OF Basal Medium (Titan Biotech Ltd., India) as described in Quinn et al. [28, 29].

Presumptive species identification of isolates was done employing secondary biochemical tests which included: tests for urease activity, fermentation of sugars such as glucose, sucrose, lactose and tests for production of indole following standard procedures described previously $[29,30]$.

\section{Molecular identification and characterization Deoxyribose nucleic acid (DNA) extraction}

Few colonies from the presumptively identified $24-48 \mathrm{~h}$ pure cultures of $M$. haemolytica and B.trehalosi were picked for DNA extraction using Qiagen DNeasy Blood and Tissue Kit as per the manufacturer's instructions (Qiagen, Germantown, MD, USA).

\section{Multiplex PCR assay for detection of virulence associated genes of M. haemolytica}

Primers targeting virulence associated genes of $M$. haemolytica viz. PHSSA (Pasteurella haemolytica serotype specific antigen) gene coding for $M$. haemolytica serotype specific antigen and Rpt2 gene loci coding for methyltransferase (Table 1) were used in multiplex PCR (mPCR) assay described in previous studies [31]. In brief, the PCR was carried out in a final volume of $25 \mu \mathrm{l}$ of reaction mixture containing $10 \mu \mathrm{l}$ of IQ Super mix (Bio Rad, USA) (DNA polymerase, dNTPs and buffer), $2 \mu \mathrm{l}$ $(5 \mathrm{pM} / \mu \mathrm{l})$ of each primer pairs, $3 \mu \mathrm{l}$ of RNase free water and $4 \mu \mathrm{l}$ template DNA. The PCR condition used was an initial denaturation at $95^{\circ} \mathrm{C}$ for $3 \mathrm{~min}$, followed by $35 \mathrm{cy}$ cles of each at $95^{\circ} \mathrm{C}$ for $1 \mathrm{~min}$, annealing at $48^{\circ} \mathrm{C}$ for 1 min and extension at $72{ }^{\circ} \mathrm{C}$ for 30 s and a final extension cycle at $72{ }^{\circ} \mathrm{C}$ for $5 \mathrm{~min}$. One reaction tube without the DNA template and the other with DNA template from reference $M$. haemolytica isolate from National Veterinary Institute culture collection (MH-NVI) were included as negative and positive controls, respectively.

\section{PCR for the detection of P. multocida}

Isolates presumptively identified as M.haemolytica and B.trehalosi were subjected to PCR assay using specific primer pairs targeting the capsular biosynthesis gene (capA) (Table 1) of $P$. multocida as described previously by Townsend et al [32].

PCR reaction mixture $(50 \mu \mathrm{l})$ containing, master mix (Fermentas, Thermo Fisher Scientific, USA), $6 \mu \mathrm{L}$ of 5 pmol of each primer (Eurofins MWG Operon, Germany), $6 \mu \mathrm{L}$ DNA template and $20 \mu \mathrm{L}$ IQ super mix were used. The amplification protocol used was an initial denaturation at $95^{\circ} \mathrm{C}$ for $5 \mathrm{~min}$, followed by 35 cycles each at $95^{\circ} \mathrm{C}$ for $1 \mathrm{~min}$, annealing at $55^{\circ} \mathrm{C}$ for $1 \mathrm{~min}$ and extension at $72^{\circ} \mathrm{C}$ for $30 \mathrm{~s}$ and a final extension cycle at

Table 1 Primer pairs flanking capsular genes of P. multocida and virulence associated genes of M. haemolytica used in the current study

\begin{tabular}{|c|c|c|c|c|}
\hline \multirow{2}{*}{$\frac{\text { Gene locus }}{\text { CapA }}$} & \multicolumn{2}{|c|}{ Primer sequence (5'- 3') } & \multirow{2}{*}{$\frac{\text { Size }(b p)}{1044}$} & \multirow{2}{*}{$\frac{\text { Reference }}{[32]}$} \\
\hline & Forward & 5'-TGCCAAAATCGCAGTCAG- 3' & & \\
\hline & Reverse & $5^{\prime}$-TTGCCATCATTGTCAGTG- $3^{\prime}$ & & \\
\hline \multirow[t]{2}{*}{ PHSSA } & Forward & $5^{\prime}$-TTC ACA TCT TCA TCC TC-3' & 325 & [31] \\
\hline & Reverse & $5^{\prime}$ TाT TCA TCC TCT TCG TC-3' & & \\
\hline \multirow[t]{2}{*}{ Rpt2 } & Forward & $5^{\prime}$ - GTT TGT AAG ATA TCC CAT TT- 3' & 1022 & [31] \\
\hline & Reverse & 5'- CGT TाT CCA CTT GCG TGA - 3' & & \\
\hline
\end{tabular}


$72{ }^{\circ} \mathrm{C}$ for $7 \mathrm{~min}$. Negative and positive controls were included one without DNA template and the other reaction tube with DNA from P. multocida strain from NVI collection (MH-NVI), respectively. Detection of the PCR products was done in $2 \%(w / v)$ agarose gel, prepared from 0.5X Tris borate EDTA buffer stained with Gelred. Each PCR product $(5 \mu \mathrm{l})$ was mixed with $6 \mathrm{X}$ loading buffer and loaded into separate well of the pre-prepared gel while $1 \mathrm{~kb}$ plus DNA molecular marker was loaded onto the first and last lane and run at $120 \mathrm{~V}$ for $60 \mathrm{~min}$ on electrophoresis apparatus (EC 2060, USA). The different band sizes of the PCR products were visualized under UV transilluminator and photographed in gel documentation system (UVI TEC, UK).

\section{Purification and sequencing of $P C R$ products}

The PCR products were purified using the Wizard SV Gel and PCR clean-up system kit (Promega, Germany) and its concentration determined using the NanoDrop 2000c spectrometer (Thermo Scientific, USA). The concentration of each purified product was adjusted and prepared according to the instruction recommended by the sequencing company and submitted for sequencing along with sequencing primers (forward and reverse) to LGC Genomics (Berlin, Germany).

\section{Phylogenetic analysis or genotyping}

Genotyping of the isolates was conducted using partial sequence data of two virulence genes, PHSSA and Rpt2 genes. Since the current isolates were from the same region i.e. central Ethiopia, genetic analysis using virulence genes is expected to provide better resolution as they are known to be under high evolutionary pressure. PHSSA and Rpt 2 gene sequences of M.haemolytica strains isolated in the current study and the accession numbers of the sequences retrieved from GenBank database used in the current analysis is presented in Table 2 .

\section{Data analysis}

Descriptive statistics were used in summarizing quantitative data when appropriate. Trace sequence data were edited and fragments were assembled using Vector NTI

Table 2 Nucleotide accession numbers of PHSSA and Rpt2 gene sequences of the current isolates and reference strains M. haemolytica included in the analysis

\begin{tabular}{|c|c|c|}
\hline Isolate & Accession no ${ }^{a}$ & Source or reference \\
\hline M. haemolytica strain ETH/Adama/21/2017 & MH220354* & This study \\
\hline M. haemolytica strain ETH/Ejere/16/2017 & MH220353*; MH220358** & This study \\
\hline M. haemolytica strain ETH/Ejere/15/2017 & MH220355*; MH220359** & This study \\
\hline M. haemolytica strain ETH-DZ/kality 26/01/2017 & $\mathrm{MH} 220357^{* *}$ & This study \\
\hline M. haemolytica strain ETH-Dalota-08/12/2016 & $\mathrm{MH} 220360^{* *}$ & This study \\
\hline M. haemolytica NVI-reference strain & $\mathrm{MH} 220356^{* *}$ & This study \\
\hline M. haemolytica strain USDA-ARS-USMARC-185 & СР004753.2 & [38] \\
\hline M. haemolytica strain M42548 & СР005383.1 & [38] \\
\hline M. haemolytica strain D174 & СР006574.1 & [39] \\
\hline M. haemolytica strain D171 & СР006573.1 & [39] \\
\hline M. haemolytica strain D153 & СР005972.1 & . [39] \\
\hline M. haemolytica strain CSWRI/AH/12/12 & KJ534629.1 & [31] \\
\hline M. haemolytica strain CSWRI/AH/11/12 & KJ566123.1 & [31] \\
\hline M. haemolytica strain $89,010,807 \mathrm{~N}$ & СР011098.1 & [40] \\
\hline M. haemolytica strain 193 & СР023043.1 & [40] \\
\hline M. haemolytica strain 191 & СР023044.1 & [40] \\
\hline M. haemolytica USDA-ARS-USMARC-184 & СР006957.2 & [38] \\
\hline M.haemolytica strain 89,010,807 N IktA & СР011099.1 & [40] \\
\hline M. haemolytica USDA-ARS-USMARC-183 & СР004752.2 & [38] \\
\hline M. haemolytica strain 187 & СР023046.1 & [38] \\
\hline M. haemolytica strain 186 & СР023047.1 & [38] \\
\hline M. haemolytica strain CSWRI/AH/MhA.16 & MF417618.1 & [41] \\
\hline M. haemolytica strain 30/30-02-16LC & MF776879.1 & [41] \\
\hline M. haemolytica serotype A1 & AF060119.2 & [42] \\
\hline
\end{tabular}

${ }^{a}$ Acc.no refer to both PHSSA and Rpt2 gene sequences; *Acc.no for only PHSSA gene; **acc.no for only Rpt2 gene 
Advance $^{\mathrm{rm}} 11.5$ software (Invitrogen, Carlsbad, CA, USA). A consensus sequence was generated for each isolate from forward and reverse sequences using BioEdit. For comparative phylogenetic analysis, blastn was used to collect additional sequence data of PHSSA and Rpt2 genes from reference $M$. haemolytica strains and isolates from other geographical areas from GenBank. All sequence analysis was conducted in MEGA version 7. Multiple sequence alignments were performed using Clustal W [33]. Phylogenetic relationships among the current isolates and isolates from other geographical areas was determined based on phylogenetic trees constructed using the Neighbor-Joining algorithm with interior-branch test and the complete deletion option with bootstrap replicates set at 1000 .

\section{Results}

M. haemolytica was found to be commonly associated with pneumonic cases of sheep in the study areas where it was isolated from 26 of the total 76 (34.21) cases while Bibersteinia trehalosi was associated with two of the cases (Table 3) although the majority of the cases were due to some other agents that need yet to be determined. The biochemical profile of the isolates presumptively identified as $M$. haemolytica and B. trehalosi is presented in Table 4.

Further molecular analyses of the isolates using primers targeting PHSSA and Rpt2 genes of M. haemolytica in a multiplex PCR assay resulted that all 26 isolates phenotypically identified as $M$. haemolytica were positive for Rpt2 gene, 21 of them being positive for PHSSA gene thus belonging to serotype A1. Nine representative $M$. haemolytica isolates positive for both Rpt2 and PHSSA genes while 5 representatives positive only for $R p t 2$ gene are shown in Fig. 1.

When analysed in a PCR assay using primers specific for capsular biosynthesis gene of P. multocida, M. haemolytica isolates included were negative resulting in rather non-specific PCR product size of about $650 \mathrm{bp}$ different from the expected 1044 bp (Fig. 2). Both isolates phenotypically identified as $B$. trehalosi were also

Table 3 Recovery rate of isolates with respect to the study areas

\begin{tabular}{lllll}
\hline Study sites & Number tested & \multicolumn{2}{l}{ Isolates } & Total \# (\%) \\
\cline { 3 - 4 } & & $\begin{array}{l}\text { M.haemolytica } \\
\text { B (\%) }\end{array}$ & $\begin{array}{l}\text { B.trehalosi } \\
\text { \# (\%) }\end{array}$ \\
\hline Addis Ababa & 11 & $2(18.18)$ & nil & $2(18.18)$ \\
Ada'a & 27 & $10(37.03)$ & $2(7.41)$ & $12(44.44)$ \\
(DZ/Kality) & & & & \\
Lome (Ejere) & 17 & $8(47.06)$ & nil & $8(47.06)$ \\
Adama & 21 & $6(28.57)$ & nil & $6(28.57)$ \\
Total & 76 & $26(34.21)$ & $2(2.63)$ & $28(36.84)$ \\
\hline
\end{tabular}

Table 4 Biochemical characteristics of the isolates presumptively identified as M. haemolytica and B. trehalosi

\begin{tabular}{lll}
\hline Reaction & Isolates (No =26) & Isolates (No =2) \\
\hline Haemolysis & + & + \\
Motility & - & - \\
Catalase & + & + \\
Oxidase & + & + \\
Growth on MacConkey & + & + \\
Indole production & - & - \\
Glucose & + & + \\
Lactose & + & - \\
Sucrose & + & + \\
Interpretation & M. haemolytica & B. trehalosi \\
\hline & &
\end{tabular}

negative for presence of both PHSSA and Rpt2 genes of $M$. haemolytica as well as for capsular gene of $P$. multocida (Fig. 3).

\section{Phylogenetic analysis}

Phylogenetic analysis based on PHSSA gene showed that $M$. haemolytica isolates from Ethiopia resolved into two genotypes consistent to the site of isolation, an isolate from Adama (ETH/Adama/21/2017) being phylogenetically related to $M$. haemolytica strains from India (CSWRI/ AH/12/12; CSWRI/AH/MhA.16 and 30/30-02-16Lc) and USA (USDA/ARS/SAM/185) while two of the isolates from Ejere, Ethiopia formed distinct cluster $(\mathrm{ETH} /$ Ejere 15/2017 and ETH/Ejere 16/2017) with another strain from USA (USDA/ARS/USMARC/184) (Fig. 4).

On the other hand, phylogenetic analysis using Rpt2 gene showed similar scenario where all isolates from the study sites were resolved into three genotypes which is consistent to the site of isolation. Two of the isolates from the same site (ETH-Ejere-16/2017 and ETHEjere-15/2017) which were analysed in both genes seem to be clonal complexes forming distinct cluster. The other two isolates (ETH-Dalota-08/12/2016 and ETHDZ/kality 26/01/2017) seem to represent distinct genotypes although strain from Dalota is closer to the ETH-Ejere clonal complex. However, the strain from ETH-DZ/kality is genetically far related to the rest of the strains from Ethiopia and any of the reference strains included in the analysis. Moreover, based on the Rpt2 gene sequence analysis all the three genotypes of $M$. haemolytica identified were far related to the M. haemolytica NVI reference strain (Fig. 5).

\section{Discussion}

The present study demonstrated that M.haemolytica was associated with one third of pneumonic cases indicating its significant role in pneumonia of sheep in central Ethiopia although other agents associated with the 


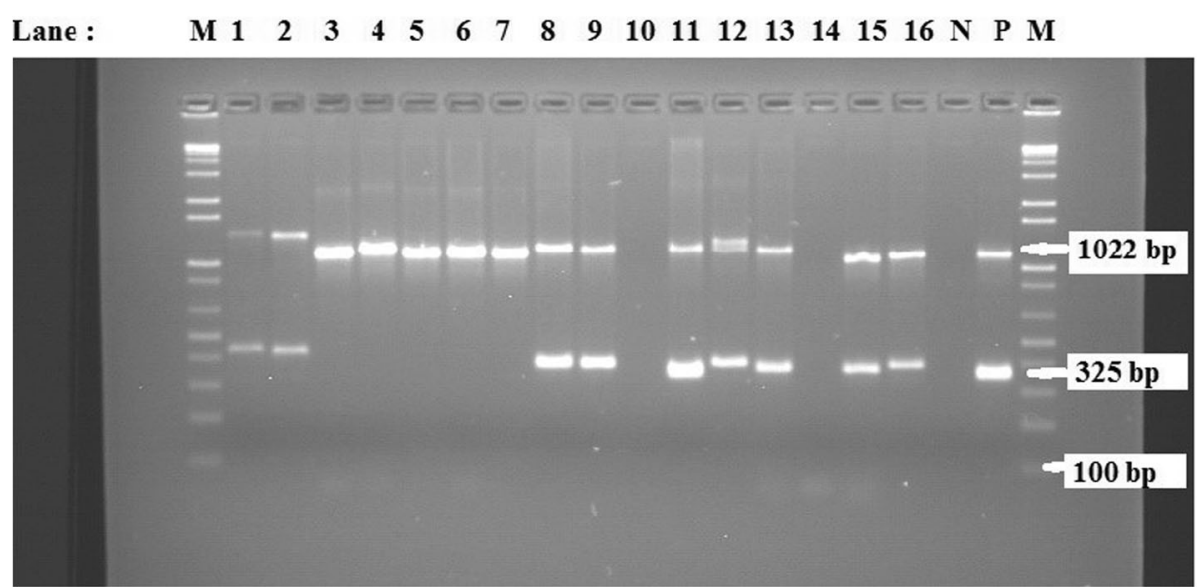

Fig. 1 Agarose gel electrophoresis showing PCR products of Rpt2 and PHSSA genes approximately 1022 and 325 bp, respectively. Lanes: M = 1 kb plus DNA molecular markers; 1-16: Isolates (lane 10 and 14: B.trehalosi isolates, please describe the other M. haemolytica positive lanes). N: Negative control-; P: positive control

remaining cases need yet to be determined. This study is the first of its kind that revealed the genotypes of $M$. heamolytica circulating among cases of pneumonic sheep in central Ethiopia.

The clinical findings observed in affected sheep were consistent with the clinical pictures associated with $M$. haemolytica and B.trehalosi infections as reported previously [14, 34, 35]. The absence of P. multocida from any of the cases investigated in contrast to $M$. haemolytica indicate the limited role of $P$. multocida in causing pneumonic pasteurellosis in central Ethiopia unlike the previous reports. The study rather indicated that $B$. trehalosi was associated with few of pneumonic cases of sheep (7.14\%) which may suggest its potential role as cause of pneumonia in the study areas although it was quite lower than previous reports of $13.4 \%$ [20] from south Wollo, Northern Ethiopia. Similar occurrence of B. trehalosi was obtained from central Ethiopia by Mekonnen [21] which was $7 \%$. The absence of P.multocida in the current study is in agreement with previous report in which P.multocida was not isolated from cases of pneumonic sheep [36].

Phenotypic methods used in the current study couldn't distinguish $M$. haemolytica from B.trehalosi except for lactose fermentation which is consistent with Korczak et al. [37] who stated that B. trehalosi is phenotypically closely related to Mannheimia. All isolates phenotypically identified as $M$. haemolytica were also confirmed to

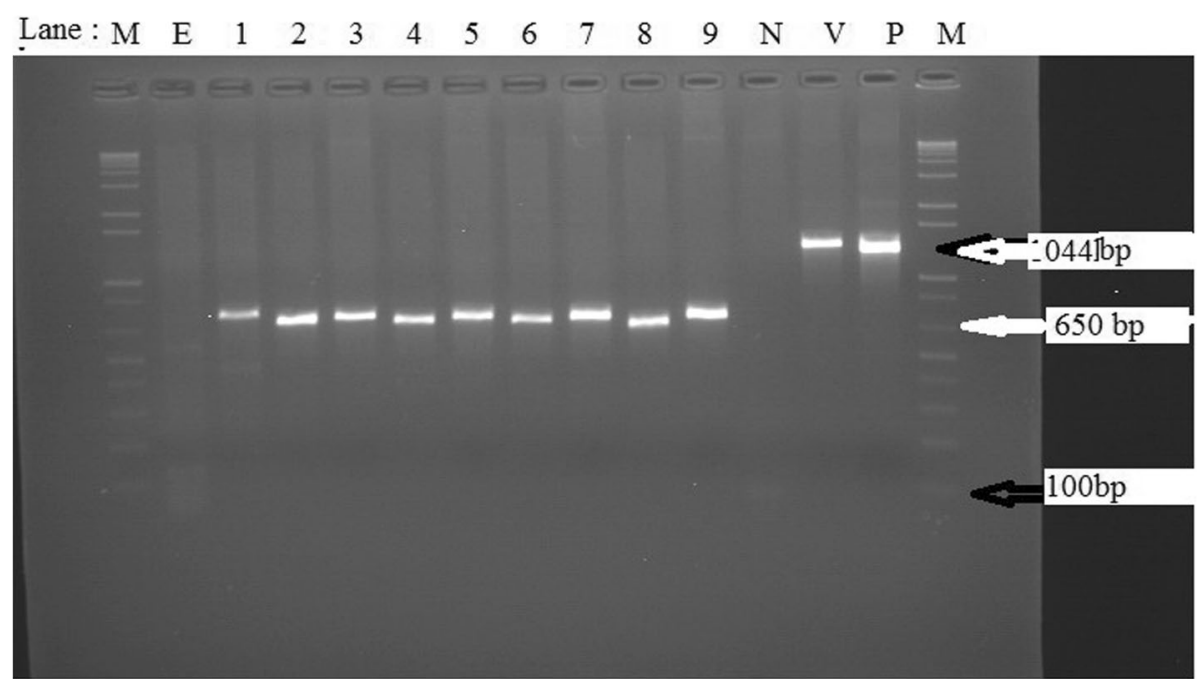

Fig. 2 Agarose gel electrophoresis showing PCR products (approximately $1044 \mathrm{bp}$ ) using primer pairs targeting capsular biosynthesis gene of $P$. multocida. Lanes: $\mathrm{M}=1 \mathrm{~kb}$ plus DNA molecular marker, E: Extraction control, Lane 1-9:M.haemolytica isolates. N: Negative control, V: NVI vaccine strain (P. multocida type A) positive around 1044 bp. P: positive control 


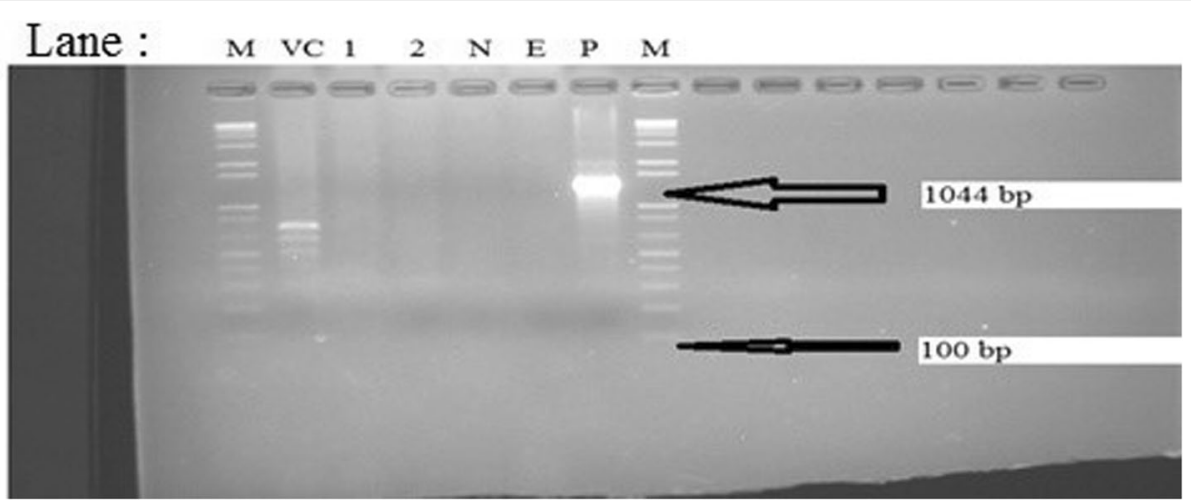

Fig. 3 Agarose gel electrophoresis showing PCR products (approximately $1044 \mathrm{bp}$ ) using primer pairs targeting capsular biosynthesis gene of $P$. multocida and $B$ trehalosi as template. Lanes: $M=1 \mathrm{~kb}$ plus DNA molecular marker, Lane VC: NVI reference strain ( $M$. haemolytica serotype A2 isolate), Lane 1-2: B. trehalosi isolates, N: Negative control; E: extraction control, P: positive control

be as such by the mPCR assay indicating that the standard phenotypic method can provide reliable identification in the absence of molecular technique.

The non-specific PCR product obtained in PCR assay targeting capsular biosynthesis gene of $P$. multocida when applied to $M$. haemolytica isolates may show that
P. multocida and M.haemolytica share common sequences in their capsular gene(s) at the primer binding site but at different positions. Isolates phenotypically identified as B.trehalosi were not detected by any of species specific primers for $P$. multocida and virulence associated genes (PHSSA and Rpt2) of M.haemolytica

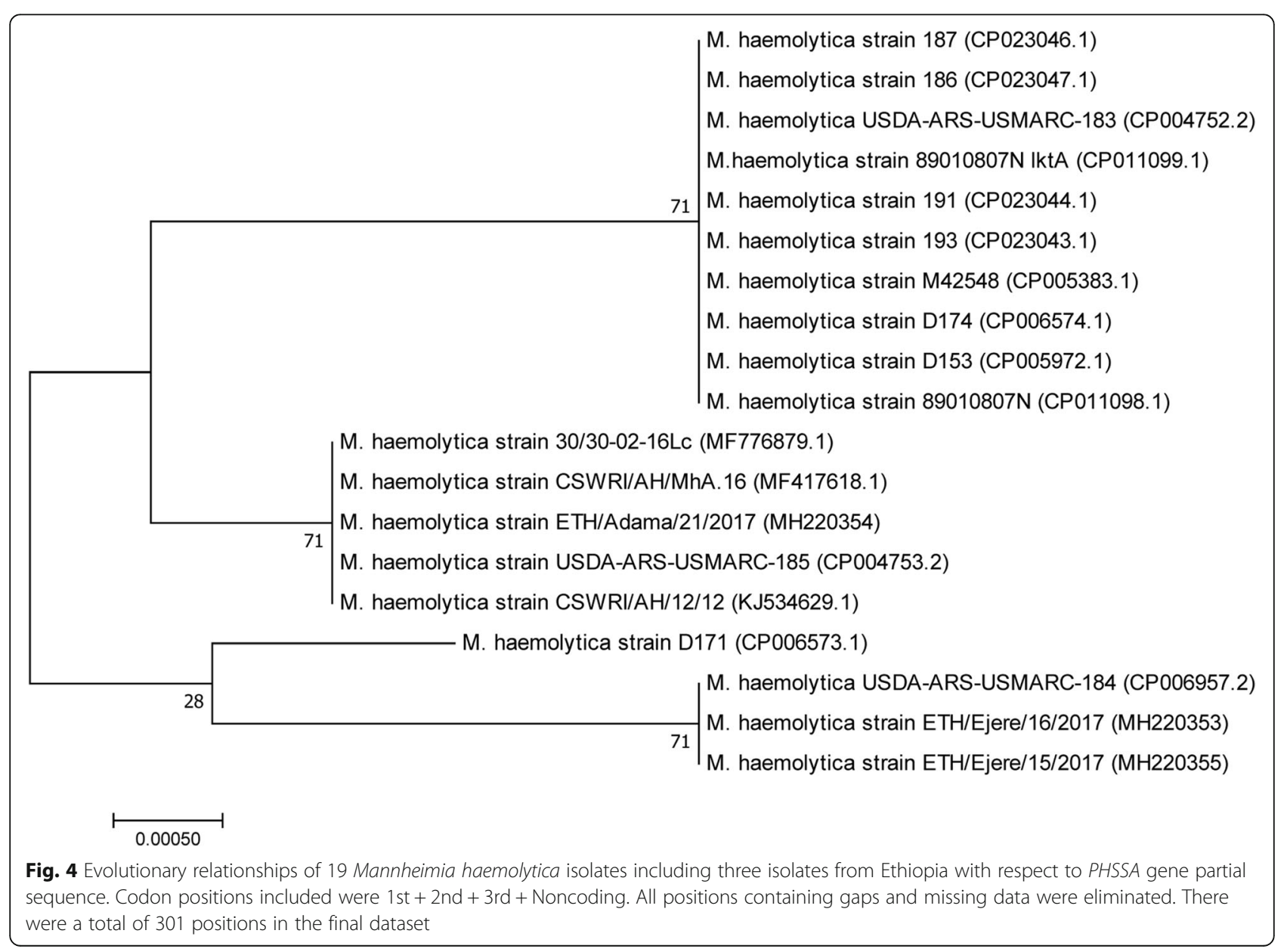




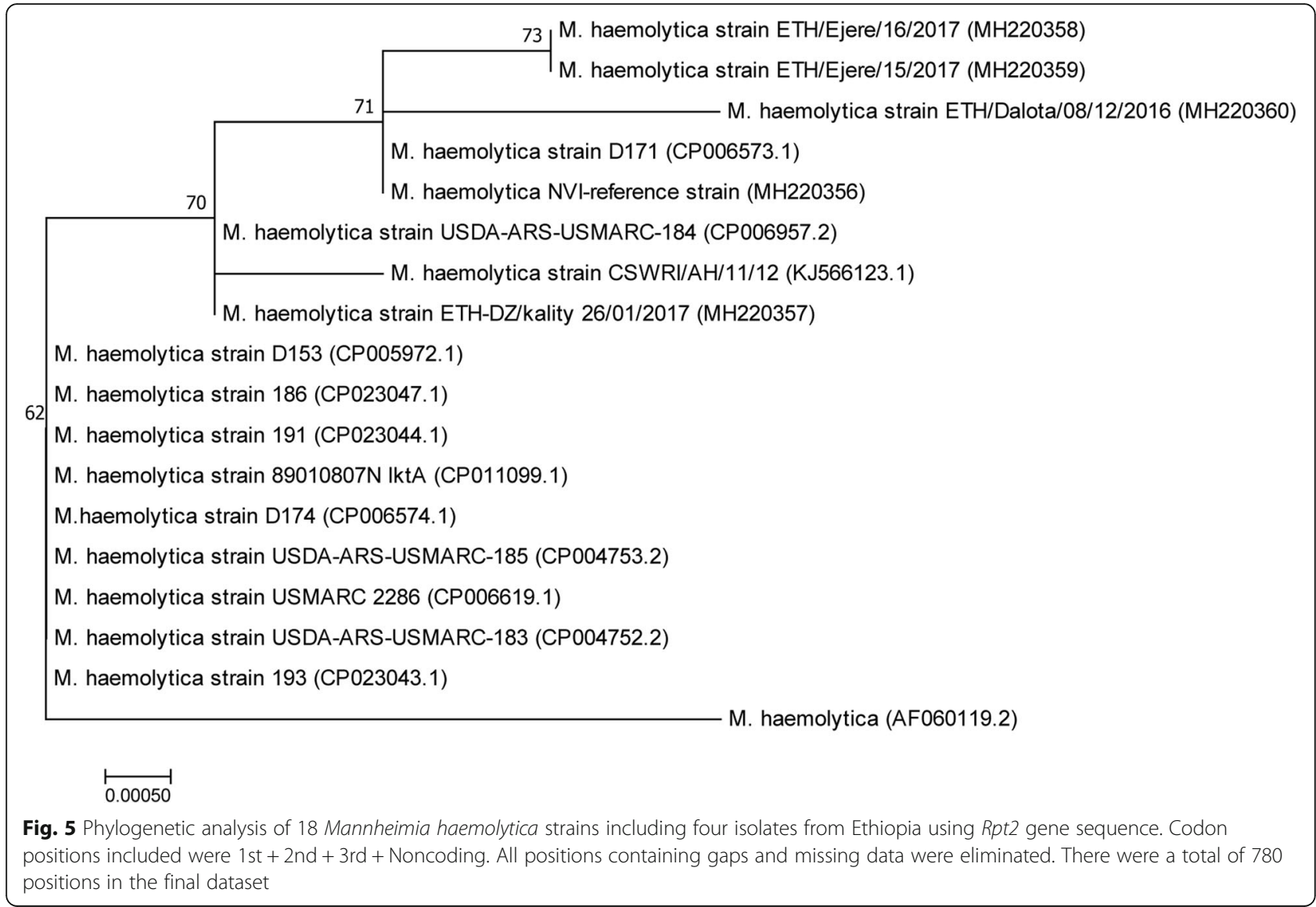

showing their genetic distinction, which is also corroborated by previous studies with respect to $r p o B$ gene [37]. $M$. haemolytica and $B$. trehalosi belong to different distinct clusters in phylogenetic analysis using the $r p o \mathrm{~B}$ gene, a gene encoding for the $\beta$ subunit of bacterial RNA polymerase [37]. The association of M. haemolytica with significant proportion of ovine pneumonic cases in the current study is in line with those mentioned by Sisay and Zerihun [26], Ayelet et al. [5], and Deressa et al. [22] in central highlands and Eastern Ethiopia where all indicated $M$. haemolytica as the main culprit of the problem. Thus, the current finding along with previous reports of the high prevalence of $M$. haemolytica serotype A2 and A8 in other parts of central Ethiopia [5] all consolidate the need for polyvalent vaccine unlike the currently used monovalent vaccine (inactivated $P$. multocida biotype A). The high rates of mortality and morbidity following respiratory distress in different parts of the country despite the annual vaccination may indicate the reduced efficacy of the currently used vaccine supporting our findings. However, assessment of outbreaks at national level to determine the role of $M$. haemolytica and other agents involved in causing pneumonia in sheep and further molecular identification of the circulating M. haemolytica serotypes is essential to have an overview on major causative agent and serotype distribution for selection of candidate vaccine strains that can provide cross protection.

The existence of three genotypes of $M$. haemolytica circulating in the study areas based on the results of phylogenetic analysis with respect to partial sequences of Rpt2 and PHSSA genes indicate the involvement of different strains of varying sources causing outbreaks. Except the $M$. haemolytica isolates from Lome Ejere, which seem to be clonal complexes, the rest of the isolates analysed belonged to diverse genotypes different from the reference local strain from NVI. This variation in genotype distribution among M.haemolytica isolates observed is in agreement with the findings of Gilmour [12] who stated that members of the genus Mannheimia are phenotypically and genotypically heterogeneous. This suggests that further nation-wide strain characterization is important with subsequent work on whether these different genotypes share common antigens which is vital for an effective vaccine development. The fact that $M$. heamolytica was found to be associated with one third of sheep pneumonic cases in the current study highlights the role of one or more or a combination of other agents in causing sheep pneumonia in the majority of the cases requiring further studies targeting all possible agents. 


\section{Conclusion}

Both phenotypic and molecular characterization confirmed that $M$. haemolytica is associated with a significant number of pneumonic cases of sheep in study areas of central Ethiopia although the role of other agents responsible for the majority of the cases is yet to be determined. Phylogenetic analysis based on partial sequences of PHSSA and Rpt2 gene of the current isolates revealed the existence of three genotypes of $M$. haemolytica circulating in the study areas, which was consistent with the site of isolation. Further extensive work to figure out strain (genotype) distribution, antigenic relationships among strains, understanding the molecular epidemiology of M.haemolytica and B.trehalosi at national level and other important agents/factors to the disease has paramount importance in designing a cost effective prevention and control method.

\section{Abbreviations}

DNA: Deoxyribose nucleic acid; mPCR: Multiplex Polymerase Chain Reaction; NVI: National Veterinary Institute; PHSSA: Pasteurella haemolytica serotype specific antigens

\section{Acknowledgements}

The authors would like to thank the National Veterinary Institute (NVI) of Ethiopia for availing the laboratory space and facilities as well as the International Atomic Energy Agency (IAEA), Austria for covering the sequencing costs. The technical support of staffs at Research and Development directorate is highly appreciated.

\section{Funding}

This work is financed by the National Veterinary Institute (NVI) of Ethiopia which has been also participated in the design and collection data.

\section{Availability of data and materials}

Nucleotide sequence data generated in this study can be accessed from GenBank Database with accession numbers from MH220353 to MH220360. All other data supporting the findings reported can be obtained from the first or corresponding author upon formal request.

\section{Authors' contributions}

AL did all laboratory works and drafted the manuscript. AL, GM, TA and EG designed the study, participated in the initial drafting and revision of the manuscript. TA and EG analyzed the data and revised the manuscript. LT and $A B$ participated in laboratory work. MY coordinated the study and revised the manuscript. All authors read and approved the final version of the manuscript.

\section{Ethics approval and consent to participate}

This study has been approved by the Animal Research Ethics Committee of the College of Veterinary Medicine and Agriculture of Addis Ababa University as regards to the ethical standards in handling and specimen collection from animals.

\section{Consent for publication}

Not applicable.

\section{Competing interests}

The authors declare that they have no competing interests.

\section{Publisher's Note}

Springer Nature remains neutral with regard to jurisdictional claims in published maps and institutional affiliations.

\section{Author details}

${ }^{1}$ National Veterinary Institute, P.O. Box 19, Bishoftu, Ethiopia. ${ }^{2}$ College of Veterinary Medicine and Agriculture, Addis Ababa University, P.O. Box 34, Bishoftu, Ethiopia.

Received: 24 April 2018 Accepted: 14 November 2018

Published online: 05 December 2018

\section{References}

1. Central Statistical Authority (CSA). Ethiopia agricultural sample enumeration. Addis Ababa: Central Statistical Authority of the Federal Democratic Republic of Ethiopia; 2015.

2. Alemayehu Z, Fletcher I. Small ruminant productivity in the central Ethiopian mixed farming system. Ministry of Agriculture, Addis Ababa. Proc. Inst Agric Res. 1991:141-7. http://agris.fao.org/agris-search/search. do?recordID=ET19950005852

3. Ademosun AA. Constraints and prospects for Small Ruminant Research and Development in Africa. In: Proceedings of the Second Biennial Conference of the African Small Ruminant Research Network, AICC, Arusha, Tanzania, 711 December 1992. ILCA (International Livestock Centre for Africa)/ CTA (Technical Centre for Agricultural and Rural Co-operation). ILCA, Addis Ababa, Ethiopia. p. 268.

4. Radostits OM, Blood DC, Gay CC. Veterinary Medicine, A text Book of the diseases of Cattle, Sheep, Pig, Goats and Horses. 8th Ed. London: Baillière Tindall; 1994.

5. Ayelet G, Yigezu L, Gelaye E, Tariku S, Asmare K. Epidemiologic and serologic investigation of multifactorial respiratory disease of sheep in the Central Highland of Ethiopia. Int J Appl Res Vet Med. 2004;2(4):274-8.

6. Davies RL, WTS A, Selander RK. Sequence diversity and molecular evaluation of leukotoxin (Itk A) gene in bovine, ovine strains of Mannheimia haemolytica. J Bacteriol. 2001;183:1394-404 Tindal, London;1994:748-785.

7. Ozbey G, Kilic A, Ertas HB, Muz A. Random amplified polymorphic DNA (RAPD) analysis of Pasteurella multocida and Mannheimia haemolytica strains isolated from cattle, sheep and goats. Vet Med Czech Republic. 2004:49(3):65-9.

8. Daniel JA, Held JE, Brake DG, Wulf DM, Epperson WB. Evaluation of the prevalence and onset of lung lesions and their impact on growth of lambs. Am J Vet Res. 2006;67(5):890-4.

9. Kadjo AL, Villard C, Bezet JL, Martel H, Sanchis T, Borges D, Guathier R, Maurin F, Hichard Y. Pulsed field gel electrophoresis is more efficient than ribotyping and random amplified polymorphic DNA analysis in discrimination of Pasteurella haemolytica strains. J Clin Microbiol. 1999;37:380-5.

10. Chen H, Halton LK, Claridge JE. Taxonomic subgroups of Pasteurella multocida correlate with clinical presentation. J Clin Microbiol. 2002;40: 4338-3441.

11. Franck GH. Pasteurellosis in cattle. In: Adlam C, Rutter JM, editors. Pasteurella and pasteurellosis. London: Academic Press; 1989. p. 197-222.

12. Rice JA, Carrasco-Medina L, Hodgins DC, Shewen PE. Mannheimia haemolytica and Bovine respiratory disease. Anim Health Res Rev. 2008;8(2):117-28.

13. Bowland S, Shewen P. Bovine respiratory disease. Commercial vaccines currently available in Canada. Can Vet J. 2000;41:33-48.

14. Radostits OM, Gay CDC, Blood, Hinchclift KW. Diseases the respiratory system. In: Veterinary medicine, a text book of the disease of cattle, sheep pigs, goats and horse. 10th ed. London: Saunders; 2006. p. 1-2160.

15. Thompson DAJ, Frasser J, Gilmour JL. Serotypes of Pasteurella haemolytica in ovine pasteurellosis. Res Vet Sci. 1977;22:130-1.

16. Ewers C, Lubke BA, Wieler LH. Mannheimia haemolytica and the pathogenesis of pneumonic pasteurellosis. Berl Munch Tierarztl Wochenschr. 2004:117(3-4):97-115.

17. Janet LG, Daniel JM, Paul ML, Michael WM. Epidemic pasteurellosis in a bighorn sheep population coinciding with the appearance of a domestic sheep. J Wildl Dis. 2008:44(2):388-403.

18. Haig S-G. Adherence of Mannheimia haemolytica to ovine bronchial epithelial cells. Biosci Horiz Int J Stud Res. 2011;4(1):50-60.

19. Biberstein $E$, Gills $M$. The relationship of the antigenic types of the a and T types of Pasteurella haemolytica. J Comp Pathol. 2002;72:316-20.

20. Sarah J. Adherence of Mannheimia haemolytica to ovine bronchial epithelial cells. Biosci Horiz. 2011:4(1):50-60.

21. Mekonnen T. An Epidemiological Study on Ovine Pasteurellosis in Arsi, Southeast Ethiopia. DVM Thesis. Debre-Zeit: Addis Ababa University, Faculty of Veterinary Medicine; 2000. 
22. Deressa A, Asfaw Y, Lubke B, Kyule M, Tefera G, Zessin K. Molecular detection of Pasteurella multocida and Mannheimia haemolytica in sheep respiratory infections in Ethiopia. Int J Appl Res Vet Med. 2004;8(2):101-8.

23. Ferede $\mathrm{Y}$, Mekuriaw S, Mazengia $\mathrm{H}$, Amane A. Sero-typing and evaluation of the level of protective antibody titre in Northwest Ethiopian sheep before and after oviner pasteurellosis vaccination. Int J Pharm Med Bio Sc. 2013; 2(4). http://www.ijpmbs.com/uploadfile/2015/0412/20150412033816770.pdf.

24. Kehrenberg C, Werckenthin C. Schwarz S. a transposon-like element from Pasteurella multocida mediating tetracycline resistance. Antimicrob Agents Chemother. 1998;42:2116-8.

25. Kehrenberg C, Gundula ST, Jean LM, Elisabeth CD, Stefan S. Antimicrobial resistance in Pasteurella and Mannheimia: Epidemiology and genetic basis. Vet Res BioMed Central. 2001;32(3-4):323-39.

26. Sisay T, Zerihun A. Diversity of Mannheimia haemolytica and Pasteurella trehalosi serotypes from apparently healthy sheep and abattoir specimens in the highland of Wollo, North East Ethiopia. Vet Res Com. 2003;27:3-14.

27. Quinn PJ, Markey BK, Leonard FC, Hartigan P, Fanning S, Fitz Patrick ES. Veterinary microbiology and Microbial Disease. 2nd ed. West Sussex: WileyBlackwell; 2011.

28. Quinn PJ, Morkey BK, Carter ME, Donnelly WJC, Lenard FC, Maguire D. Pasteurella species and Mannheimia haemolytica. In: Veterinary microbiology and microbial diseases, 1st ed. London: Black Well Science Ltd; 2002. p. 137-42.

29. Carter GR. Diagnostic Procedures in Veterinary Bacteriology and Mycology. 4th ed. Springfield: Charles Thomas Publishers; 1984. p. 3-19.

30. Hawari AD, Hassawi DS, Sweiss M. Isolation and identification of Mannheimia haemolytica and Pasteurella multocida in sheep and goats using biochemical tests and random amplified polymorphic DNA (RAPD) analysis. J Biol Sci. 2008;8(7):1251-4.

31. Kumar J, Dixit SK, Kumar R. Rapid detection of Mannheimia haemolytica in lung tissues of sheep and from bacterial culture. Vet Worl. 2015;8(9):1073-7.

32. Townsend KM, Boyce JD, Chung JY, Frost AJ, Adler B. Genetic organization of Pasteurella multocida cap loci and development of a multiplex capsular PCR typing system. J Clin Microbiol. 2001;39:924-9.

33. Tamura K, Stecher G, Peterson D, Filipski A, Kumar S. Molecular evolutionary genetics analysis version 60. Mol Biol Evol. 2013;30:2725-9.

34. Gilmour NJL, Gilmour JS. Pasteurellosis of sheep. In: Adlam C, Rutter JM, editors. Pasteurella and Pasteurellosis. London: Academic Press; 1989. p. 223-62.

35. Gilmour NJL. Pasteurella haemolytica infections in sheep. Vet Quart. 1980;2: 191-8.

36. Demissie T, Dawo F, Sisay T. Biochemical and antigenic characterization of Mannheimia, Pasteurella and Mycoplasma species from naturally infected pneumonic sheep and goats, Bishoftu, Ethiopia. Afri J Bas Appl Sci. 2014; 6(6):198-204.

37. Korczak B, Christensen H, EmLer S, Frey J, Kuhnert P. Phylogeny of the family Pasteurellaceae based on rpoB sequences. Int J Syst Evol Microbiol. 2004;54:1393-9.

38. Harhay GP, Koren S, Phillippy AM, McVey DS, Kuszak J, Clawson ML, Harhay DM, Heaton MP, Chitko-McKown CG, Smith TP. Complete closed genome sequences of Mannheimia haemolytica serotypes A1 and A6 isolated from cattle. J Gen Ann. 2013;1 (3):E00188-13.

39. Hauglund MJ, Tatum FM, Bayles DO, Maheswaran SK, Briggs RE. Genome sequences of Mannheimia haemolytica serotype A2 isolate D171 and D35, recovered from bovine pneumonia. J Gen Ann. 2015;3(2). https://www.ncbi. nlm.nih.gov/pubmed/25767233.

40. Heaton MP, Harhay GP, Smith TP, Bono JL, CG C-MK. Complete closed genome sequences of a Mannheimia haemolytica serotype A1 Leukotoxin deletion mutant and its wild-type parent strain. J Gen Ann. 2015;3(3):1.

41. NCBI database. Mannheimia haemolytica strain 30/30-02-16LC serotype 1 specific antigen gene, partial cds. Bethesda: National Library of Medicine; 2018. https:/www.ncbi.nlm.nih.gov/nuccore/MF776879.1. Accessed 18 Jan 2018.

42. Ryan KA, Lo RY. Characterization of a CACAG pentanucleotide repeat in Pasteurella haemolytica and its possible role in modulation of a novel type III restriction-modification system. J Nucleic Acids Res. 1999;27(6):1505-11.

Ready to submit your research? Choose BMC and benefit from:

- fast, convenient online submission

- thorough peer review by experienced researchers in your field

- rapid publication on acceptance

- support for research data, including large and complex data types

- gold Open Access which fosters wider collaboration and increased citations

- maximum visibility for your research: over $100 \mathrm{M}$ website views per year

At BMC, research is always in progress.

Learn more biomedcentral.com/submissions 